\title{
Methods for predicting the energy value of pet foods
}

\author{
Carlos Castrillo', Marta Hervera², Maria Dolores Baucells ${ }^{2}$
}

\author{
${ }^{1}$ Departamento de Producción Animal y Ciencia de los Alimentos - Universidad de Zaragoza. Miguel Servet, 177 - 50013 - Zaragoza, Spain. \\ 2 Grup de Recerca en Nutrició, Maneig i Bienestar Animal - Universitat Atònoma de Barcelona - 08193 - Cerdanyola del Vallès, Spain.
}

\begin{abstract}
The energy value of foods as well as energy requirements of dogs and cats is currently expressed in terms of metabolizable energy (ME). The determination of ME content of foods requires experimental animals and is too expensive and time consuming to be used routinely. Consequently, different indirect methods have been proposed in order to estimate as reliably an accurately as possible the ME content of pet food. This work analyses the main approaches proposed to date to estimate the ME content of foods for cats and dogs. The former method proposed by the NRC estimates the ME content of pet foods from proximal chemical analysis using the modified Atwater factors, assuming constant apparent digestibility coefficients for each analytical fraction. Modified Atwater factors systematically underestimate the ME content of low-fibre foods whereas they overestimate those that are high in fibre. Recently, different equations have been proposed for dogs and cats based in the estimation of apparent digestibility of energy by the crude fibre content, which improve the accuracy of prediction. In any case, whatever the method of analysis used, differences in energy digestibility related with food processing and fibre digestibility are unlikely to be accounted for. A simple in vitro enzymatic method has been recently proposed based in the close relationship that exist between energy digestibility and organic matter disappearance after two consecutive enzymatic (pepsin-pancreatin) incubation of food sample. Nutrient composition and energy value of pet foods can be also accurately and simultaneously predicted using near infrared reflectance spectroscopy (NIRS).
\end{abstract}

Key Words: energy evaluation, pet foods, indirect methods

\section{Métodos para predição do valor energético de alimentos pet}

RESUMO - O valor energético dos alimentos, bem como os requerimentos em energia para cães e gatos são expressos em termos de energia metabolizável (EM). A determinação do conteúdo de EM dos alimentos requer ensaios com animais e apresentam alto custo. Consequentemente, diferentes métodos indiretos tem sido propostos para estimar o conteúdo de EM dos alimentos PET. Este artigo analisa os principais métodos propostos para estimar o conteúdo de EM dos alimentos para cães e gatos. O método formal proposto pelo NRC estima o conteúdo de EM dos alimentos pet a partir da análise proximal usando fatores Atwater, assumindo coeficiente de digestibilidade aparente constante para cada fração analizada. Os fatores "Atwater" modificados, sistematicamente, subestimam o conteúdo de EM de alimentos com baixa fibra e superestimam para os alimentos com alto conteúdo de fibra. Recentemente, diferentes equações tem sido propostas para cães e gatos, baseadas na estimação da digestibilidade aparente da energia pelo conteúdo de fibra bruta, as quais melhoram a precisão da predição. Em todo caso, qualquer que seja o método de análise usado, diferenças relatadas na digestibilidade da energia e digestibilidade da fibra com alimentos processados dificilmente são explicadas. Um método enzimático in vitro simples tem sido proposto recentemente, baseado na relação que existe entre digestibilidade de energia e o desaparecimento da matéria orgânica de amostras de alimentos após duas incubações enzimáticas consecutivas ( pepsina-pancreatina). A composição em nutrientes e o valor energético de alimentos pet podem ser, simultaneamente, e de forma precisa, preditos, usando espectroscopia de refletância infra vermelho (NIRS).

Palavras-chave: avaliação energética, alimentos pet, métodos indiretos

\section{Introduction}

Why is it important to know the energy value of dog and catfood?

All metabolic processes in animal organism involve a transfer and expediture of energy, the only source of which is food. The potential of a food to supply energy is therefore of great importance in determining its nutritive value. The energy density of diet determines the amount of food to be given daily and consequently, knowledge of food energy content is critical for the reliable use of commercial diets. Furthermore, energy density of food determines the concentration that must have in other nutrients (such as amino acids, minerals, vitamins) in order to cover animal requirements. 


\section{Expressing pet food energy density}

Following the International System Units, energy is expressed in work units (joule), but in physiological studies it has been usually expressed in terms of thermodynamic caloric units (calories), based in the caloric value of benzoic acid as the reference standard, that is equal to 4.184 joules. In this work we will use calories as the unit of measure, given that it is the unit generally used in the American continent, in contrast $t$ Europe where the joule is the preferred unit of expression used nowadays.

\section{Bioavailability of energy: energy categories}

The potential energy a food can provide after complete oxidation of the organic matter is known as gross energy (GE), which is measured by complete combustion of food in a bomb calorimeter. The amount depends on the proportion of fat, proteins and carbohydrates, which on average have a GE content of 9.4, 5.7 and $4.1 \mathrm{kcal} / \mathrm{g}$, respectively (NRC, 2006).

Only a part of this energy is available and useful to the animal. Some energy is lost in faeces, urine, gases, and in form of heat. The first stage to be considered in energy bioavailability is digestibility. When faecal energy losses are discounted from GE, the apparent digestible energy content of food (DE) is obtained. A large number of factors affect the digestibility of food (Shields, 1993). Among animal factors, not only the specie ( $\operatorname{dog} s v s$ cats), but also breed, gender, age, activity, physiological state, health and even individual characteristics may affect digestibility. Within animals, energy digestibility of food varies with nutrient composition. Digestibility of fats is usually higher than that of proteins. Carbohydrates from plant cell content generally show an intermediate digestibility, whereas cell wall carbohydrates are no available to small intestine digestive enzymes of dogs and cats, although may, to a limited extent, be fermented in the hind-gut. Ingredients that provide nutrients and food processing also affect energy digestibility, as well as the amount of food consumed.

The next stage of energy bioavailability is metabolicity of digestible energy. Metaboli zable energy (ME) represents DE minus energy losses in urine and gases. Losses in urine are essentially of urea and basically depend on the balance between digested and retained protein, although in cats and $\operatorname{dog} s$ that are fed conventional diets they rarely exceed a ten percent of GE, even assuming a nitrogen balance equal to zero (Kendall et al., 1992a; Castrillo et al., 2001b). Energy losses in the form of gases (mainly gas methane) arising from hind gut fermentation are negligible in carnivorous animals (McKay \& Eastwood, 1984).
The last stage in energy bioavailability is the transformation of ME into net energy (NE). When animals are fed there is an increase in heat production (heat increment) mainly due to the inefficiency with which the energy of absorbed nutrients replaces mobilised reserves of the animals (mainly fat) to yield ATP when food is given below maintenance, and the inefficiency with which the energy of absorbed nutrients is employed in the synthesis and retention of fat, protein, or lactose in the case of milk, once maintenance requirements are covered. A minor part of heat increment is due to the energy cost of food apprehension, digestion, absorption and heat resulting from colonic fermentations.

The efficiency of ME utilization $(\mathrm{k})$ varies with the function for which the ME is utilised and with the composition of the food consumed. Although there are few data on the efficiency of ME utilisation in dogs and cats, Blaxter (1989) estimated the heat increment to be $15 \%$ ME below maintenance and 30\% ME above maintenance in dogs. In pigs and poultry that are fed balanced diets the efficiency of MEutilization varies between 0.85 and 0.90 for maintenance and between 0.6 and 0.8 for growth (McDonald et al., 2002). The efficiency of ME utilisation for growth also varies with the composition of the gains given that ME is utilised more efficiently for fat deposition (kf) than for protein deposition (kp). Experimental data in literature obtained in rats and pigs show kp values ranging from 0.43 to 0.60 and $\mathrm{kf}$ values ranging from 0.65 to 0.80 .

It has been also shown in several species that the efficiency of ME utilization varies with the chemical nature of the energy-yielding nutrients. In simple-stomach animals it mainly depends on the protein content of their foods, because dietary protein is used less efficiently than carbohydrates and fat, both for maintenance and growth. When protein is used to provide energy for maintenance, there is an appreciable heat increment of about $20 \%$ compared to carbohydrates and lipids, which is in part associated to the energy required for urea synthesis (McDonald et al., 2002), and the theoretical efficiency with which the energy of carbohydrates, lipids and protein is employed in the synthesis of fat can be calculated stechiometrically to be $0.80,0.96$ and 0.66 (Blaxter, 1989). The NRC (2006) states that this effect is likely to be very small. However, given the great variation in the protein content of dog and cat diets currently on the market, this effect may be relatively important. Nguyen et al. (2000) estimated that diets with similar ME but different protein content may differ by $12 \%$ in their NE content. The content of fermentable fibre may also affect the efficiency of ME 
utilization, because of the lower efficiency of volatile fatty acids in relation to glucose to yield ATP, but this effect would have very little impact on dogs and cats.

Although the energy evaluation approach that considers all stages (NE) is the most precise, it requires more knowledge and experimental data in relation to the third stage, and obtaining such data is very costly and requires the use of direct or indirect calorimetry. Thus the energy value of foods, as well as energy requirements of dogs and cats, has so far been expressed in terms of DE or ME (NRC, 2006; AAFCO, 2008; FEDIAF, 2008).

\section{Experimental measurement of $M E$ content of pet foods}

The "gold standard" for determining DE and ME is feeding trials with direct measurement of the energy consumed and lost in faeces and urine. Although ME determination also requires the measurement of gas losses, in dogs and cats these losses of fermentation can be disregarded, as mentioned previously. AAFCO (2008) and FEDIAF (2008) protocols recommend a minimum of 5 days adaptation to diet and 5 days of quantitative collection. These periods may be reduced in dogs to a 3-day adaptation and 4-day collection without reduction in accuracy (Nott et al., 2006). This is not however the case in cats, which exhibit more variable consumption and excretion patterns. Indigestible markers, such as $\mathrm{Cr}_{2} \mathrm{O}_{3}$, may also be used to determine nutrients and energy digestibility without the need of quantitative collection of faeces.

AAFCO (2008), FEDIAF (2008) and NRC (1985, 1986, 2006) suggest a short-cut method to calculate the ME content of pet foods, without the need of urine collection. ME can be determined with little lost of accuracy by subtracting 1.25 and $0.86-0.90 \mathrm{kcal}$ per $\mathrm{g}$ of digestible crude protein (DCP) to the experimentally determined DE, in dogs and cats, respectively. When the ME is calculated in this way it is assumed that animals are in $\mathrm{N}$-equilibrium. A similar factor for urine energy losses in dogs was proposed a long time ago (Rubner, 1885) and later confirmed (Oshima et al., 1993; Castrillo et al., 2001b).

Laflamme (2001) applied the factor proposed by the NRC showing a very high correlation between experimental and estimated ME in cat foods ( $r=0.99-1.00)$. Estimated values differed by less than $1 \%$ overall from experimental ME. The author concludes that experimental determined or calculated energy urinary losses may be used interchangeably in cats. In any case, differences in $\mathrm{ME}$ resulting from the use of different $\mathrm{N}$-correction factors are rather small, between 1 and $4 \%$ depending of the protein content of the food.
Indirect estimation of $D E$ and $M E$ content of pet foods from chemical composition

The in vivo determination of ME content of foods, although technically easy to implement, requires of animals and is too expensive and time consuming to be used in routine quality control monitoring in feed plants or for food control officers to check the statements made on the labels. In vivo digestion trials are not an option either for diet evaluation in nutrition consultation practice. Consequently different indirect methods have been proposed in order to estimate as reliably and accurately as possible the ME content of pet food, using variables that can be easily analysed at a reasonably low cost and with good reproducibility. Moreover, is also advisable for the predictive equations to have a physiological basis to allow its adaptation to new products in the market.

There are different approaches to estimate the energy value of diets for dogs and cats without the need to carry out in vivo balance trials:

1. Using tabulated data on the digestibility of food ingredients.

2. By factorial models based on proximate chemical analyses of foods.

3. By empirical models including independent variables, directly or indirectly responsible for GE and average energy digestibility of food.

4. Using models based on the determined or estimated GE content of foods and the estimation of its digestibility from its fibre content

\section{Use of tables}

Data from tables may be used to estimate the DE or ME content of diets, assuming individual values of each ingredient are additive. However, data for dog and particularly for cats are scarce and the method is not applicable $t$ industrialy prepared pet foods, because ingredient composition is only known by the manufacturer and the effects of processing cannot be taken into account. Their use is only recommended for homemade and semipurified diets of known composition and formulated with usual ingredients.

\section{Predictive equations of ME from proximate analysis}

\section{Factorial approach}

The first predictive equation of ME based on the chemical composition of food was proposed more than 100 years ago by Rubner (1885) in Germany and by Atwater $(1902 ; 1910)$ in USA. They were based on the combustion 
heat of protein, fat and carbohydrate, corrected for losses in digestion, absorption and urinary energy excretion. Rubner proposed factors of 4.1,9.3 and 4.1 kcal of ME per gram of protein, fat and carbohydrate. Atwater in his later work suggested the simplified factors 4, 9 and $4 \mathrm{kcal}$ of $\mathrm{ME}$ per gram of protein, fat and carbohydrate (total carbohydrates).

This equation can only predict ME with reasonable degree of precision if the digestibility of the diets to which it is applied is close to the digestibility of the diets that were used to obtain the equation. Atwater factors were developed for foods consumed by humans and the digestibility considered for carbohydrates, fat and protein is very high (96, 96 and 91 given GE values of 4.15, 9.4 and $5.65 \mathrm{kcal} / \mathrm{g}$ for carbohydrates, fat and protein, and renal losses of 1.25 $\mathrm{kcal} / \mathrm{g}$ protein; NRC, 1985). Kienzle (2002), found a close correlation $(\mathrm{r}=0.98)$ between predicted ME values, calculated applying this factors, and ME values obtained from a review of the literature on composition and determined energy and protein digestibility. However, although there was a very good agreement for all high-energy foods, discrepancies occurred when the equation was applied to foods with a higher content of non-starch polysaccharides, which were overestimated. Consequently, original Atwater factors are recommended only for home-made diets formulated with unprocessed food and human food of a high digestibility and for liquids for enteral nutrition (NRC, 2006). The NRC (2006) also point out that Atwater factors do not work as well for cats because the digestibility of nutrients, particularly fat, is lower in cats than in dogs (Kendall et al., 1982b). In cats, a factor of 8.5 instead 9.0 is proposed for fat. Moreover, Atwater factors do not reflect differences in urinary energy losses between dogs and cats.

The original Atwater factors clearly overestimate ME when applied to commercial pet foods, which usually have a nutrient digestibility of under $90 \%$ (Kendall et al, 1982a,c; Kendall et al, 1985; NRC, 1986), therefore they were modified according to the digestibility of the diets to which they were applied. The modified Atwater factors $(3.5 \mathrm{kcal} /$ $\mathrm{g}$ for nitrogen free extracts -NFE- and crude protein -CP- and $8.5 \mathrm{kcal} / \mathrm{g}$ for fat; NRC, 1985) were determined on the basis of an average digestibility of $90 \%$ for fat, $85 \%$ for NFE and $80 \%$ for protein, derived from standard pet foods typically on the market in the 70s and early 80s. Modified Atwater factors are currently accepted by AAFCO (2008), FEDIAF (2008), and by European law (EU Commission Directive 95/ 10/EC) as a manageable method to determine the ME of dog and cat foods intended for particular nutritional purposes. However, the NRC (1985) already advised that these average values may result in underestimation of the ME content of low-fibre, low-connective-tissue-containing meat and animal by-product foods and in an overestimation of foods primarily from plant and cereal sources that contain elevated fibre contents.

This has been later proved in dogs by Kienzle et al. (1998b), Castrillo et al. (2001a) and Laflamme (2001). Predicted values underestimated in vivo values of dog foods with ME content above $3.8 \mathrm{kcal} \mathrm{DE} / \mathrm{g} \mathrm{DM}$ or $3.6 \mathrm{kcal}$ $\mathrm{ME} / \mathrm{g} \mathrm{DM}$, which are mostly found in the current dry extruded pet food market. Figure 1 shows the relationship between calculated (assuming NRC factors, 4.52 (5.64 x $0.8), 8.46$ and $3.5 \mathrm{kcal} \mathrm{DE} / \mathrm{g} \mathrm{CP}, \mathrm{EE}$ and carbohydrates) and determined DE (kcal/g DM), using our current database of 120 extruded dog food. The relationship was defined by the equation: DEcal. $=1.49 \pm 0.11+0.63 \pm 0.02$ DEdet., $\mathrm{r}=0.92, \mathrm{rsd}=0.13 \mathrm{kcal} / \mathrm{g}, \mathrm{CV}=3.0 \%$. The intercept was significantly different from zero and the slope was different from unity. Calculated DE underestimates determined DE in foods higher than $4.0 \mathrm{kcal} \mathrm{DE} / \mathrm{g} \mathrm{DM}$, that represented $75 \%$ of the total, and the opposite happens in lower energy foods.

Kienzle (2002), using a FEDIAF database of cat foods $(\mathrm{n}=83$ ), found a relationship between predicted and determined ME (kcal/g) defined by the equation: MEpredicted $=1.82+0.51 \times$ MEdetermined, $r=0.88$, which shows that, as occurs with dog foods, predicted ME underestimate experimental ME in foods with more than

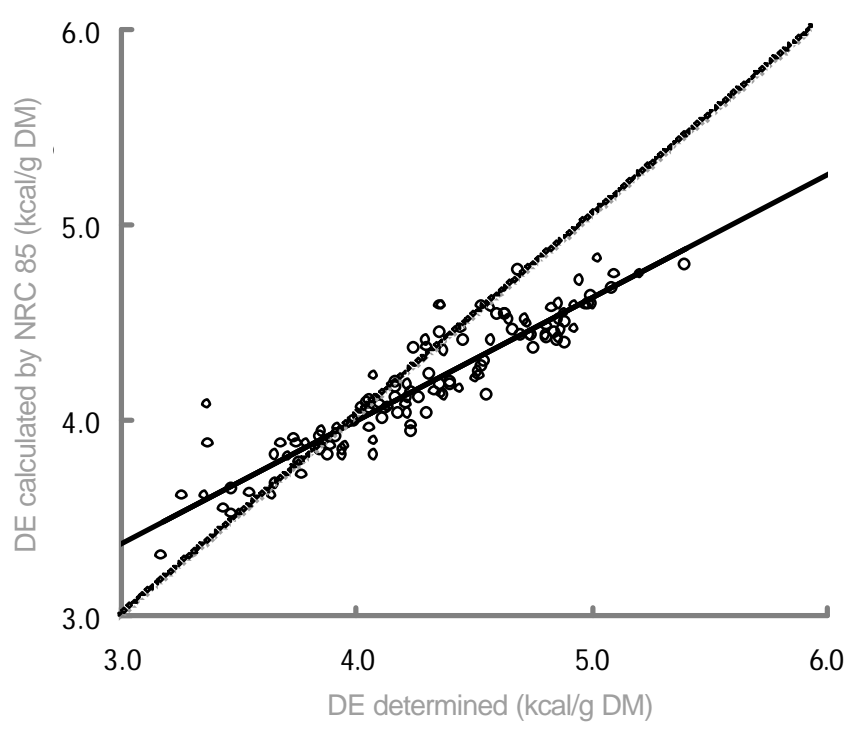

Figure 1 - Relationship between determined and calculated $\mathrm{DE}(\mathrm{kcal} / \mathrm{gDM})$ (assuming NRC, 1985 factors; 4.52 (5.64 x 0.8), 8.46 and $3.5 \mathrm{kcal} \mathrm{DE} / \mathrm{g} \mathrm{CP}, \mathrm{EE}$ and carbohydrates) ( $\mathrm{n}=120$ extruded dog food, own database).

(DE cal. $=1.49 \pm 0.11+0.63 \pm 0.02$ DEdet. $, \mathrm{r}^{2}=085, \mathrm{rsd}=0.127$ $\mathrm{kcal} / \mathrm{g}, \mathrm{CV}=3.0 \%$ ) 
$3.7 \mathrm{kcal} \mathrm{ME} / \mathrm{g}$ DM, which accounted for most of the foods in the database.

In conclusion, current studies agree that the enormous variability of prepared pet foods on nowadays market does not make it advisable the use of just one equation with constant factors for the macronutrients for the prediction of ME. In fact, modified Atwater factors systematically underestimate the ME content of low-fibre foods in the high-energy range whereas they overestimate those in the low-energy range, which generally contain high proportions of plant sources and fibre.

\section{Empirical equations}

The use of constant factors for the chemically-defined entities used in factorial equations is not tenable, not only because constant digestibilities are assumed for each nutrient, but also because the latest proposals assumes that fibre does not provide energy and moreover they do not reflect the complex interrelationships between the chemical constituents. It is well documented that part of the fibre is fermented in the hind gut (Fahey et al., 1990b; Silvio et al., 2000) and also the negative effect of fibre on the apparent digestibility of fat, protein and available carbohydrates (Livesey, 1993; Kienzle et al., 1998a, 2001; Castrillo et al., 2001a).

For such reasons those concerned with estimating the metabolisable energy of feeds for domesticated livestock and also for pets have adopted empirical approaches based on simple and multiple regression models in which the metabolisable energy of feeds are predicted from certain chemical determinations. Table 1 shows some of the predictive equations obtained so far with dog and cat foods.

Equations including only GE or EE as independent variables $(1,2,5,6,7,8,9,10)$ predict $\mathrm{DE}$ and $\mathrm{ME}$ with reasonable precision. This is because fat has approximately twice the energy content of dietary protein and carbohydrates and is thus the main nutrient influencing the GE of the diet. In addition, diets which are higher in fat tend to have greater total digestibility and high-fat diets are often formulated for animals with high energy requirements, for which reason they have low levels of fibre.

However, Khulman et al.(1993) tested equations (5), (7) and (8) with 14 dry cat foods showing that on average they underestimated in vivo values by 10,12 and $18 \%$. Laflamme (2001) also showed that equation (7) underestimated by $12.1 \%$ the ME content of 14 dry cat foods tested and the NRC (2006) showed an average underestimation of $1 \%$ to $8 \%$ of in vivo ME dry cat foods when using equation (5). Equations (9) has been tested with both cat and dog foods
(Kienzle \& Butterwick, 2000; Laflamme, 2001; Kienzle, 2002), and in general has proved to predict in vivo ME with reasonable precision, although it overestimated the ME of high-fibre low-energy foods. An overestimation of ME in high-fibre diets can be expected because equation based on GE or EE do no discriminate between available and unavailable carbohydrates.

Some improvement in accuracy may be achieved when a parameter related to food fibre content is included in the equations. Castrillo et al. (2001a) found that DE content of extruded dog foods can be accurately predicted from just $\mathrm{EE}$ and $\mathrm{CF}$ (equation 16) ( $\mathrm{r}=0.97, \mathrm{CV}=2.5 \%)$. Kienzle et al. (1998b) also found a close relationship between determined DE and calculated DE using equation (11) for cat foods and equations (14) and (15) for dog foods $(r=0.88,0.96$ and 0.94, respectively), when these equations were applied to the same data with which were they developed. However, when equations were tested with an independent set of data (27 cat foods and $61 \mathrm{dog}$ foods), the accuracy was much lower $(r=0.83)$ with equation $(11)$ and $r=0.65$ with equations (14) and (15).

The best empirical equation for DE (kcal/g DM) prediction, using our database of 120 extruded dog foods was obtained using GE (kcal/g DM) and CF (g/g DM) as independent variables: $\mathrm{DE}=-1.94 \pm 0.21+1.26 \pm 0.04 \mathrm{GE}-$ $6.00 \pm 0.50 \mathrm{CF}, \mathrm{r}=0.97, \mathrm{rsd}=0.104, \mathrm{CV}=2.4 \%$.

Empirical equations must be considered as a whole, reflecting GE, average digestibility of nutrients and the complex inter-relationships between nutrients in the set of data used to develop them. Consequently, they usually work well as long as the diets which are used to develop the equations are similar in terms of the quality of ingredients and processing to the diets to which the equations are applied to, but can not be applied to the general range of pet foods. Hence, specific equations must be developed for different types of foods, and this would require a huge database.

Equations based on the prediction of energy digestibility from fibre content

Recently, equations have been proposed based on the estimation of apparent digestibility of energy from the fibre content of food. The estimate $\mathrm{dE}$ is then multiplied by the heat of combustion of food, either measured in a bomb calorimeter or estimated from nutrients, and a correction for urinary energy losses, estimated from the crude protein content of foods, is also applied to estimate ME. The NRC (2006), AAFCO (2008) and FEDIAF (2008) recommend this approach (Table 2) as the best method to predict ME of pet foods, assuming the factors and equations proposed by Kienzle et al. (1998b), the only exception being the factor 
Table 1 - Some empirical equations described in literature. Energy expressed in kcal/g and nutrients en g/g

Cats

Kendall et al. (1982a)

Composition expressed on" as is" bases (DM $=19.4 \%, \mathrm{n}=43$ )

(1) $(22$ canned foods $) \mathrm{ME}=1.00 \mathrm{GE}-0.238, \mathrm{rsd}=0.043, \mathrm{r}=0.98, \mathrm{CV}=5.3 \%$

(2) (43 canned foods) $\mathrm{DE}=0.83 \mathrm{GE}-0.05, \mathrm{rsd}=0.054, \mathrm{r}=0.96, \mathrm{CV}=6.6 \%$

(3) (22 canned foods) $\mathrm{ME}=3.9 \mathrm{CP}+7.7 \mathrm{EE}+3.0 \mathrm{NFE}$ (total carbohydrates) $-0.051 \mathrm{rsd}=0.059, \mathrm{r}=0.97, \mathrm{CV}=7.3 \%$

(4) $(43$ canned foods) $\mathrm{DE}=4.2 \mathrm{CP}+7.5 \mathrm{EE}+2.7 \mathrm{NFE}$ (total carbohydrates) $-0.0126 \mathrm{rsd}=0.076, \mathrm{r}=0.92, \mathrm{CV}=9.3 \%$

Composition expressed on "as is" bases ( $\mathrm{DM}=90.7 \%, \mathrm{n}=28)$

(5) (14 packeted foods) $\mathrm{ME}=0.99 \mathrm{GE}-1.260, \mathrm{rsd}=0.147, \mathrm{r}=0.73, \mathrm{CV}=5.0 \%$

(6) (28 packeted foods) $\mathrm{DE}=0.97 \mathrm{GE}-0.815, \mathrm{rsd}=0.295, \mathrm{r}=0.55, \mathrm{CV}=9.2 \%$

Kendall et al. (1985).

Composition expressed on "as is" bases, (mean DM=91.7\%)

(7) $(28$ dry foods) $\mathrm{ME}=0.84 \mathrm{GE}-0.60, \mathrm{rsd}=0.15 ; \mathrm{r}=0.88, \mathrm{CV}=5.1 \%$

(8) $(28$ dry foods $) \mathrm{ME}=3.98 \mathrm{EE}+2.60, \mathrm{rsd}=0.19 ; \mathrm{r}=0.81(\mathrm{CV}=6.5 \%)$

Khulman et al. (1993). 14 dry commercial cat foods

Composition expressed on "as is" bases (mean DM=92.0\%)

(9) ( 14 dry foods) $\mathrm{ME}=1.21 \mathrm{GE}-1.911, \mathrm{r}=0.95 \mathrm{rsd}=0.14, \mathrm{CV}=3.5 \%$

(10) (14 dry foods) $\mathrm{ME}=0.075 \mathrm{EE}+2.766, \mathrm{r}=0.96 \mathrm{rsd}=0.13, \mathrm{CV}=3.3 \%$

Kienzle (1998b)

(11) $(\mathrm{n}=58) \mathrm{DE}=4.92 \mathrm{CP}+7.79 \mathrm{EE}+3.42 \mathrm{NFE}-0.31 \mathrm{CF}, \mathrm{r}=0.88, \mathrm{rsd}=0.196$.

Nguyen et al. (2000)

(12) $(70$ canned foods $): \mathrm{ME}=3.49 \mathrm{CP}+9.27 \mathrm{EE}+4.21 \mathrm{NFE}^{1}(\mathrm{r}=0.72)$

(13) $(31$ dry foods $): \mathrm{ME}=4.61 \mathrm{CP}+9.54 \mathrm{EE}+3.19 \mathrm{NFE}^{1}(\mathrm{r}=0.93)$

Dogs

Kienzle (1998b)

(14) $(\mathrm{n}=128) \mathrm{DE}=5.11 \mathrm{CP}+8.94 \mathrm{EE}+3.49 \mathrm{NFE}-2.87 \mathrm{CF}, \mathrm{r}=0.96, \mathrm{rsd}=0.280, \mathrm{CV}=6.5 \%$ assuming DE $=4.30 \mathrm{kcal} / \mathrm{g})$

$(15)^{*}(\mathrm{n}=107) \mathrm{DE}=5.02 \mathrm{CP}+8.37 \mathrm{EE}+3.99 \mathrm{NFE}-2.87 \mathrm{TFe}, \mathrm{r}=0.94, \mathrm{rsd}=0.196, \mathrm{CV}=4.6 \%$ assuming $\left.\mathrm{DE}=4.30 \mathrm{kcal} / \mathrm{g}\right)$

Castrillo et al. (2001)

(16) $(38$ dry foods) $\mathrm{DE}=3.58+7.21 \mathrm{EE}-15.45 \mathrm{CF}, \mathrm{r}=0.966, \mathrm{rsd}=0.112, \mathrm{CV}=2.5 \%$

Gröner and Pfeffer (1997)

(17) $(\mathrm{n}=45) \mathrm{DE}=4.92 \mathrm{CP}+9.25 \mathrm{EE}+3.73 \mathrm{NFE}-10.73 \mathrm{CF}, \mathrm{r}=0.99, \mathrm{rsd}=0.109$

${ }^{1}$ Estimated by difference between (MO-CP-EE-Total dietary fibre).

$* \mathrm{TFe}=$ Total fibre following Englyst \& Cummings (1988).

applied to EE to estimate GE (9.4 instead of 9.08 proposed by these authors). However, the NRC (2006) advise that the proposed equations may be inaccurate for dog foods with more than $8 \%$ of CF in dry matter.

The key factor of this approach is the accuracy of energy digestibility prediction from CF content of food. The negative effect of CF content on energy digestibility has a clear physiologic base as has been discussed extensively elsewhere (Kienzle, 2002, 2006). Crude fibre includes most of cellulose and a variable part of hemicelluloses and lignin, with are plant cell wall constituents not available to intestinal enzymes and with a very low or null fermentation in the hind-gut of dogs and cats (at least in the case of cellulose and lignin). Moreover, as discussed above, fibre impairs the apparent digestibility of other nutrients.

The lower slope of the regression of $\mathrm{dE}$ in $\mathrm{CF}$ in cats compared with dogs may seem odd because it would mean that fibre has a lower effect on nutrient digestibility in cats, but this may be due to the fact that dog diets are generally richer in cereals, so the $\mathrm{CF}$ could be associated with a higher proportion of non digestible carbohydrates not included in the CF fraction.

\section{Constraints of the NRC (2006) approach}

\section{Step 1. Calculated vs. determined GE}

When GE is calculated instead of measured in calorimeter bomb a certain degree of uncertainty is introduced. Differences of up to $20 \%$ between determined and calculated GE were found in some samples by Kienzle et al. (1998b) applying a combustion heat of 4.7,9.1 and $4.1 \mathrm{kcal} / \mathrm{g}$ for CP, $\mathrm{EE}$ and $\mathrm{NFE}+\mathrm{CF}$, respectively. Using a database of $61 \mathrm{dog}$ 
Table 2 - NRC (2006) proposal to predict ME content of pet foods from dE estimated by crude fibre

Step 1. Determine GE by bomb calorimeter, or calculate GE by the equations

$\mathrm{GE}(\mathrm{kcal} / \mathrm{g})=(5.7 \times \mathrm{g}$ protein $)+(9.4 \times \mathrm{g}$ fat $)+(4.1 \times \mathrm{g} \mathrm{NFE}+\mathrm{CF})$

Step 2. Estimation of percentage of energy digestibility $(\mathrm{dE})$ by the equations:

Dogs: $\mathrm{dE}(\%)=91.2-(1.43 \times \% \mathrm{CF}$ in dry matter $)$

Cats: $\mathrm{dE}(\%)=87.9-(0.88 \times \% \mathrm{CF}$ in dry matter $)$

Step 3. Calculation of digestible energy content (DE) of food:

$\mathrm{DE}(\mathrm{kcal})=\mathrm{GE} \times \mathrm{x}$ percentage of energy digestibility/100

Step 4. Prediction of urine energy losses by equations:

Dogs: Urine energy losses $=1.04 \mathrm{x} \mathrm{g} \mathrm{CP}$

Cats: Urine energy losses $=0.77 \times \mathrm{g} \mathrm{CP}$

Step 5. Prediction of metabolisable energy (ME) content of food:

$\mathrm{ME}(\mathrm{kcal})=\mathrm{DE}-$ predicted urine energy losses

foods the correlation between predicted and determined ME (with their own proposed approach assumed by NRC, 2006) increased from 0.59 to 0.95 depending on whether GE was calculated or determined by bomb calorimeter. However, Kienzle et al. (2002b) determined the GE content of different relatively purified sources of fat, protein and carbohydrates, and found, in general, a good agreement between determined a calculated values assuming NRC (2006) factors, concluding that residuals were not enough to explain the discrepancies of up to $20 \%$ found in previous work. Moreover, Castrillo et al. (2001b) did not show any improvement in the relationship between predicted (following NRC approach) and experimental DE using either calculated $(\mathrm{r}=0.978, \mathrm{CV}=2.0 \%)$ or experimental $\mathrm{GE}$ values $(\mathrm{r}=$ $0.960, \mathrm{CV}=2.7 \%$ ) and Kienzle et al (2006) using a huge database of $\operatorname{dog} s(n=610$ samples $)$ and cats $(n=261$ samples $)$ foods, found a very close relationship between calculated (using the NRC proposed factors for CP, EE and carbohydrates) and determined GE values ( $r=0.97$ and 0.96 in dog and cat foods, respectively). However, the bias induced by the calculation of GE from proximate nutrients can be easily avoided by measuring GE directly.

Figure 2 shows the relationship between determined and calculated GE (assuming NRC factors) using our current database of $120 \mathrm{dog}$ foods. The correlation was relatively close $(r=0.90)$ and the CV low $(2.7 \%)$. Neither the intercept differed significantly from zero or the slope from unity, and only one calculated value differed by more than $10 \%$ and seven by more than $5 \%$ from determined GE.

The NRC (2006) equation for dogs was obtained from 129 food databases in which CF content ranging from less than $1 \%$ to about $14 \% \mathrm{CF}$ in dry matter, although most of them fell between 1 and 6\% \% CF (Earle et al., 1998; Kienzle et al., 1998a). The correlation coefficient was not remarkable (in fact CF only explained $28 \%$ of $\mathrm{dE}$ variation, $\mathrm{rsd}=6.3$, $\mathrm{CV}=$ approximately $7.5 \%$ ). For the development of the cat equation the database was smaller $(n=58)$ and although it also comprised a huge range of $\mathrm{CF}$ content (from less than $1 \%$ to more than $30 \% \mathrm{CF}$ ), $85 \%$ of foods fell between $0 \%$ and $5 \% \mathrm{CF}$. Crude fibre explained $64 \%$ of dE variation and CV was approximately $4.5 \%$. This means that even if the proposed equations covers a large range of prepared dog and cat foods, they are not very robust and undoubtedly represent the greatest source of imprecision in the estimation of ME by this approach.

However, Kienzle et al. (1998a) showed that there were small changes in the proposed equation for dogs when the

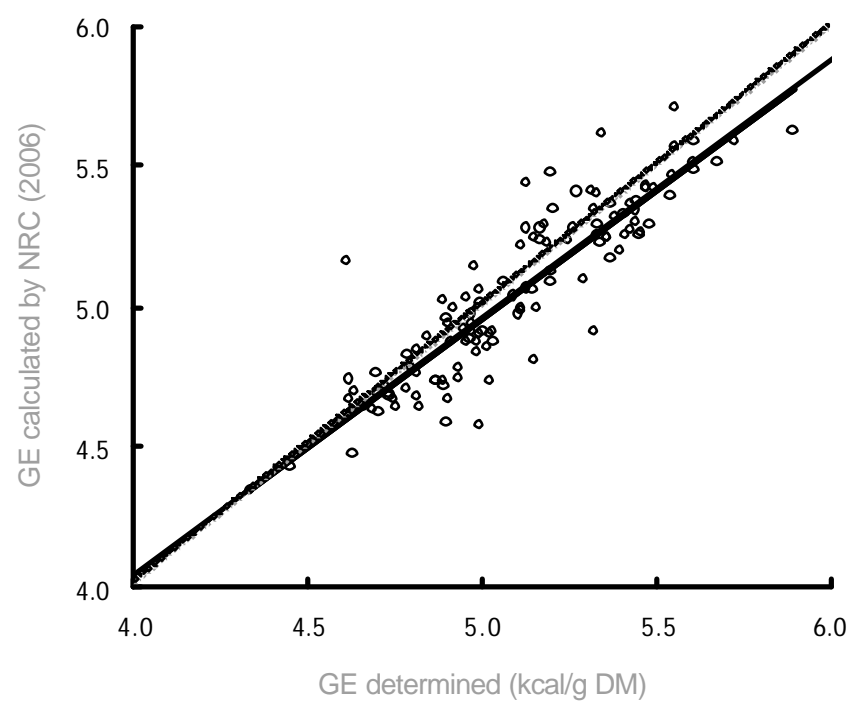

Figure 2 - Relationship between determined and calculated GE (assuming GE values of 5.7, 9.4 and $4.1 \mathrm{kcal} / \mathrm{g}$ for CP, EE and carbohydrates, NRC, 2006) $(\mathrm{n}=120$ extruded dog foods).

$\left(\right.$ GEcal. $=0.369 \pm 0.212+0.916 \pm 0.040$ GEdet., $r^{2}=0.805$, $\mathrm{rsd}=0.136 \mathrm{kcal} / \mathrm{g}, \mathrm{CV}=2.7 \%$ ). 
database was extended to 234 foods, including 44 from Gröner \& Pfeffer (1997) obtained with unconventional diets $(\mathrm{dE}(\%)=90.7-1.59 \mathrm{CF}(\%), \mathrm{r}=-0.59, \mathrm{rsd}=5.5)$. Furthermore Kienzle et al (2006), using a set of data of 495 dry dog foods, found a very similar relationship between $\mathrm{dE}$ and $\mathrm{CF}$ to that published in 1998 and a higher coefficient of correlation $(\mathrm{dE}(\%)=92.9-1.60 \mathrm{CF}(\%), \mathrm{r}=-0.87)$. It should be noted that although $\mathrm{CF}$ contents ranged from 0.7 to $23.4 \% \mathrm{DM}$, most of them fell between a range of $0.7 \%$ and 5.0\% DM, and a higher dispersion of data and a trend to a lower slope in the upper range of CF can be deduce from the figure showing the relationship between $\mathrm{dE}$ and CF. In fact, when Kienzle et al (1998a) established this relationship using only their own dog food database $(n=27)$, with CF contents between $0.07 \%$ and $5.85 \%$, a much steeper descent of $\mathrm{dE}$ with $\mathrm{CF}$ was found $(\mathrm{dE}(\%)=$ 93.42-4.25 CF(\%), $\mathrm{r}=-0.84, \mathrm{rsd}=3.90, \mathrm{CV}=4.5 \%)$. Castrillo et al. (2001b) found a similar relationship with 38 extruded dog foods ranging from $0.8 \%$ to $3.3 \% \mathrm{CF}(\mathrm{dE}=94.0-4.04$ $\mathrm{CF}(\%), \mathrm{r}=-0.85, \mathrm{rsd}=1.90, \mathrm{CV}=2.2 \%)$. The differences in the steep of slopes depending on the range of CF content in the database considered, suggest that the effect of fibre on digestibility is higher in the lower ranges of CF rather than in the higher ranges.

When our current database $(n=120)$ was used, the relationship between $\mathrm{CF}$ and $\mathrm{dE}$ (Figure 3 ) was defined by the linear equation: $\mathrm{dE}(\%)=89.3 \pm 0.40-1.84 \pm 0.11 \mathrm{CF}(\%)$, $\mathrm{r}=-0.83, \mathrm{rsd}=2.78, \mathrm{CV}=3.3 \%$ ). However, the figure clearly shows that the effect of $\mathrm{CF}$ on $\mathrm{dE}$ was less in food with a $\mathrm{CF}$ content of more than $5 \%$ DM.

The adjustment of data to a curvilinear equation or a segmented regression with two different branches depending of CF content can be envisaged. When data in figure 4 were split in to lower and higher than $5 \% \mathrm{CF}$, the following equations were obtained:

Lower range of $\mathrm{CF}(\mathrm{n}=106): \mathrm{dE}(\%)=93.15-3.87 \mathrm{CF}$ $(\% \mathrm{DM}), \mathrm{r}=0.79, \mathrm{rsd}=2.30, \mathrm{CV}=2.7 \%$.

Higher range of $\mathrm{CF}(\mathrm{n}=14): \mathrm{dE}(\%)=85.68-1.27 \mathrm{CF}$ $(\% \mathrm{DM}), \mathrm{r}=0.71, \mathrm{rsd}=2.32, \mathrm{CV}=3.1 \%$.

As pointed out by Kienzle \& Opitz (1999), the higher dispersion of estimated vs determined dE values in highfibre low-energy diets can be simply explained by mathematical reasons. Errors in faecal analysis have a greater repercussion in low digestibility diets than in high ones. Furthemore, in diets in the upper range of fibre, it may be supplied by very different sources that may have different apparent digestibilities and impair the digestibility of other nutrients to a varying extent (Diez et al., 1998). Another source of variation can be the proportion of connective

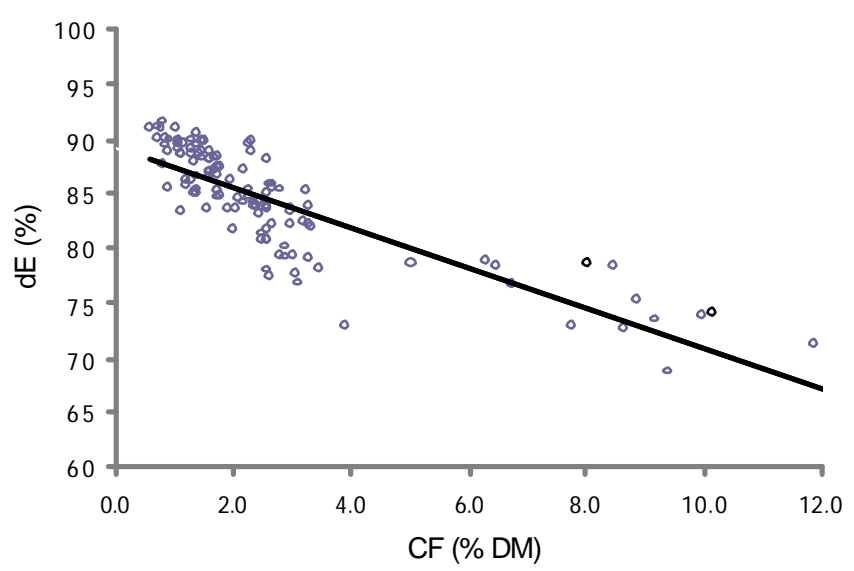

Figure 3 - Relationship between $\mathrm{CF}(\% \mathrm{DM})$ and $\mathrm{dE}(\%)$ in extruded dog foods $(n=120)$, and adjusted lineal equation: $\mathrm{dE}=89.3 \pm 0.40-1.84 \pm 0.11 \mathrm{CF}(\% \mathrm{DM})$, $\left.\mathrm{r}^{2}=0.69, \mathrm{rsd}=2.78, \mathrm{CV}=3.3 \%\right)$

tissue in diets, since certain $\mathrm{N}$-compounds from connective tissue may appear analytically as crude fibre and these compounds may have a higher apparent digestibility than other compounds determined as crude fibre (Banta et al. 1979), and they are not likely to affect the digestibility of other nutrients.

The lower impact of CF in energy digestibility in highfibre diets may be related to the type of ingredients providing the fibre. In foods low in CF (up to 3-4\%), the fibre comes mainly from cereals, with a variable proportion of other nonstarch polysaccharides not included in the CF fraction but of limited digestibility or fermentability in the gut. Moreover, in diets high in fibre this is usually increased by the inclusion of more fermentable ingredients, such as beet pulp, or by the inclusion of insoluble sources, such as pure cellulose, that probably have a lower impact on the digestibility of other nutrients and does not imply an increase in other non-starch polysaccharides of low digestibility.

Castrillo et al. (2001b) found that when NFE was introduced as a second independent variable in addition to $\mathrm{CF}$, it was negatively related to $\mathrm{dE},(\mathrm{dE}=101.8-3.38 \mathrm{CF}$ $\left.(\% \mathrm{DM})-0.21 \mathrm{NFE}(\% \mathrm{DM}) ; \mathrm{r}^{2}=0.82 ; \mathrm{rsd}=1.53, \mathrm{CV}=1.8 \%\right)$, increasing explained variation by $10 \%$ given that the NFE fraction is estimated by difference, including those cell wall components that are incompletely recovered in CF residue, but are resistant to digestion in small intestine.

Kienzle et al. (2001) suggested different equations for the estimation of energy digestibility as a function of CF for high and low-NFE diets for dogs. When data were split into high and low-carbohydrate foods (NFE greater 
than or less than $40 \%$ dry matter), the regression coefficients for fibre were 2.21 and 0.98 , respectively. Teshima et al. (2007) assessed the accuracy of NRC (2006) equation for ME prediction of 26 foods dry dog foods with NFE contents over $500 \mathrm{~g} / \mathrm{kg}$ DM. Predicted ME was in poor agreement with in vivo values $(\mathrm{r}=0.72)$, and a new equation from their set of samples was proposed $(\mathrm{GEd}=97.1-4.13 \mathrm{CF}, \mathrm{r}=0.92)$. The slope of this equation was similar to that obtained by Castrillo et al. (2001) whose set of samples averaged $446 \pm 9.8 \mathrm{~g} \mathrm{NFE} / \mathrm{kg}$ DM, with most of samples being over $400 \mathrm{~g}$ NFE/kg DM.

In an attempt to resolve some of the limitations that $\mathrm{CF}$ may have in predicting the energy digestibility of pet diets other analytical fibre fractions have been tested to predict digestible energy content of pet foods.

Earle et al. (1998) and Kienzle et al. (1998a) compared various methods of fibre analysis in $27 \mathrm{dog}$ foods and 24 cat foods and assessed their potential as dE predictors. The fibrous fractions that had a closer relationship with apparent digestibility of energy were those that included cellulose. In dogs, better correlations were found using total dietary fibre (TDF), insoluble fibre (IF), acid detergent fibre (ADF) or cellulose (ADF-acid detergent lignin) rather than $\mathrm{CF}$ as independent variables, but $\mathrm{CF}$ explained over $70 \%$ of the variation of energy digestibility. In cats there was not evidence of any studied fibre fractions improving the precision of $\mathrm{dE}$ estimation over $\mathrm{CF}$, which explained $79 \%$ of dE variation.

Kienzle et al. (1998b) found a better adjustment between measured DE and calculated values when these were estimated from TDF (Englyst \& Cumming, 1988) than when $\mathrm{CF}$ was used as predictor $(\mathrm{r}=-0.98$ vs $-0.94, \mathrm{rsd}=0.456$ vs $1.074 \mathrm{kcal} / \mathrm{g}$, respectively), but the authors pointed out that the better adjustment with TDF may have been due in part to a higher uniformity of the database used to establish the equation and because all trials and analyses were carried out using the same methods in the same laboratory, which was not the case of the database used to establish the equation with CF. However, recent studies (Kienzle et al., 2006) also suggest more accurate results using TDF rather than CF for dry dog foods. These authors, using a data base of 610 and 495 dry dog foods, respectively, found more accurate predictions of $\mathrm{dE}$ with TDF (Prosky et al., 1985) $(r=-0.94)$ than with CF $(r=-0.87)$. However, the authors emphasised that whether or not the equation using TDF can be generalised to moist foods, which may contain more fermentable fibre, should be investigated before a general recommendation can be made. We have also tested different fibre fractions other than $\mathrm{CF}$, including neutral detergent fibre, ADF and TDF and IF, and no evident improvement in prediction accuracy has been obtained.

Nevertheless CF is an easy and cheap to perform method that is widely used in most of pet food assay laboratories, and required by law to appear as composition information on pet food labels (European Directive 79/373/ EEC), making it more useful as a parameter estimator of $\mathrm{dE}$ than total or insoluble dietary fibre, which is more difficult to asses, more labour intensive, more expensive and not as widely used in pet food laboratories.

\section{Step 4. Prediction of urine energy losses}

The correction factor applied toDE to take into account the urinary energy losses ( 1.04 and $0.77 \mathrm{kcal} / \mathrm{g} \mathrm{CP}$, en dogs and cats, respectively), were proposed by Kienzle et al. (1998a) assuming urinary losses of 1.24 and 0.90 (0.86 in the original paper) $\mathrm{kcal} / \mathrm{gDCP}$ and mean protein digestibility of 0.83 for dogs and 0.86 for cats. Castrillo et al. (1998a), found a close relationship between urinary energy losses corrected for a $\mathrm{N}$ balance equal to zero and $\mathrm{CP}$ in $\operatorname{dog}$ foods, defined by the equation : $\mathrm{UE}(\mathrm{kcal} / \mathrm{g}$ food $\mathrm{DM})=0.028+1.00 \mathrm{CP}(\mathrm{g} /$ $\mathrm{g} \mathrm{DM}), \mathrm{r}=0.99, \mathrm{CV}=5.5 \%$. The intercept was not different from zero and when the slope was forced to pass through the origin, the slope was $1.09 \pm 0.175 \mathrm{kcal}$ urinary energy losses/g CP, only slightly lower than the proposed factor, because the mean CPD of foods used in this work (0.846) was also slightly higher than that in the work of Kienzle et al. (1998a).

\section{Test of proposed equations}

Laflamme (2001) used the equations proposed by Kienzle et al. (1998b) (with GE calculated using 5.7, 9.1 and 4.1 factors for CP, EE and NFE) to predict the ME content of 17 dry cat foods and 24 dry dog foods. In cat foods, calculated ME values explained $87 \%$ of the variation of determined (DE experimental $-0.86 \mathrm{kcal} / \mathrm{g}$ DCP) values, although calculated ME underestimated on average $4.5 \%$ of determined ME and underestimation was more systematic in high-energy diets. In dog foods, calculated ME values explained $91 \%$ of the variation of determined (DE experimental $1.25 \mathrm{kcal} / \mathrm{g}$ DCP). However, the agreement between calculated and experimental ME was poor in foods with ME content lower than $3.1 \mathrm{kcal} / \mathrm{g}$.

Kienzle (2002), using a set of 83 cat foods found a good correlation $(\mathrm{r}=0.96)$ between calculated and determined ME but, despite the goodness of fit, for high-fibre low-energy diets there was a tendency to overestimate ME and there were two outliers deviating more than $15 \%$ of determined values.

Kienzle et al. (1998b), using a database of 194 dog 
foods, and Kienzle et al. (2006), using a database of $495 \mathrm{dog}$ foods, found a tendency to ME overestimation of high-fibre low-energy foods, when predicted from the equations proposed by former authors and NRC (2006). Similar results were obtained using our database of 120 extruded dog foods (Figure 4). Predicted DE by NRC (2006) proposal (using measured GE values) tended to overestimate highfibre low-energy foods.

In conclusion, the new approach adopted by the NRC (2006) predicts, with reasonable precision, the ME of dog and cat foods, and is currently the most accurate method for predicting the ME content of commercially prepared per foods from chemical analyses. However, in dog foods with high CF content the accuracy of prediction decrease and there is in general a tendency to overestimate their DE or ME content, although the opposite may occur in foods with very high fibre content. A similar trend has been shown in cats, although in this case a larger number of observations are needed in order to propose robust equations. Logically, the use of determined GE instead that calculated from proximate nutrients is preferred. In any case, the effect of differences in apparent fibre digestibility between different sources and differences in food processing is unlikely to be predicted by any chemical analysis. Moreover, factors other than the CF content may affect the organic matter and energy digestibility. Furthermore, the CF content in most commercial extruded foods is very low and its determination is not very accurate.

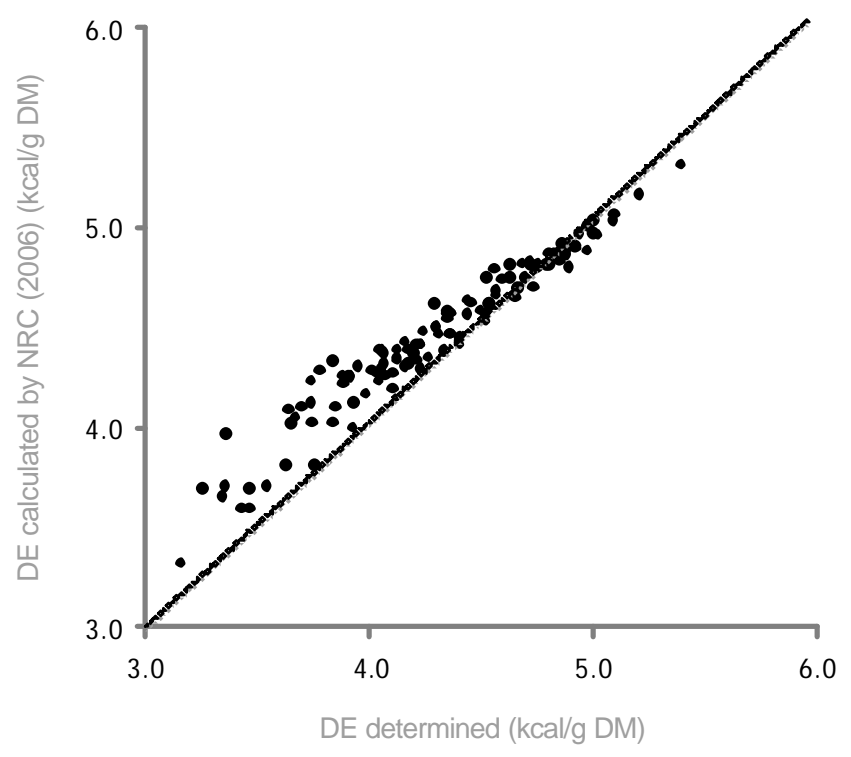

Figure 4. Relationship between experimentally determined and calculated (NRC, 2006 proposal) DE in extruded dog foods $(n=120)$.

DEcalc. $(\mathrm{kcal} / \mathrm{g})=1.14 \pm 0.07+0.77 \pm 0.02$ DEdet. $(\mathrm{kcal} / \mathrm{g}), \mathrm{r}^{2}=$ $0.94, \mathrm{rsd}=0.09, \mathrm{CV}=2.0 \%$ )
The use of enzymes to determine organic matter disappearance in vitro may help to improve the accuracy of ME prediction, particularly in diets high in fibre.

\section{In vitro approach}

Many methods have been developed to try to simulate the digestion process by enzymatic food treatment in optimal $\mathrm{pH}$ conditions. In vitro methods have evolved from very simple methods which consist in the incubation of substrate with a single enzyme, to sophisticated methods trying to control most of variables influencing in vivo digestion, such as that proposed by Smeets-Peeters et al. (1999). The former have been applied mainly to estimate protein digestibility and do not take in consideration the multiple enzymes acting in the digestion of fat, starch and proteins, and the latter, more complex methods, are not suitable for rutine food evaluation. For this purpose, the most useful methods are the multi-enzyme "filtration" methods, consisting on consecutive enzyme incubations in a closed system followed by measurement of the unsoluble material remaining after incubation. Boisen \& Eggum (1991) and Boisen (2000) have published comprehensive reviews of methods applied mainly in pigs. The methods proposed to date consist of two or three incubation steps. Two-step methods try to simulate the pre-colon digestion, using consecutive incubation, generaly with pepsin and pancreatin. Three-step methods try to simulate overall digestion by adding a third incubation with ileum or cecal bacterial inocula or a mixture of fibre-degrading enzymes. Both methods have been used to estimate ileal and faecal dE in pig food with good results (Boisen \& Fernandez, 1991; Boisen \& Fernández, 1997).

Recently Hervera et al. (2007) have developed an in vitro method for predicting the apparent energy digestibility of dry extruded dog foods, based on the twostep multi-enzymatic incubation assay described by Boisen (1991). The method consists of two consecutive incubations, the first with pepsin, at $\mathrm{pH} 2.0$ for $2 \mathrm{~h}$, and the second with pancreatin for $4 \mathrm{~h}$ at $\mathrm{pH}$ 6.8. In vitro $\mathrm{OM}$ disappearance of 54 dry extruded commercial dog foods was determined and used as predictor of the in vivo dE. Figure 5 shows the linear relationship between the in vivo $\mathrm{dE}$ and in vitro $\mathrm{dOM}$. The in vitro dMO explained $92 \%$ of in vivo $\mathrm{dE}$ variation $(\mathrm{CV}=1.5 \%)$, and neither the slope of the equation differed significantly from the unit nor the intercept differed from zero. This close relationship betweenin vivo $\mathrm{dE}$ and in vitro $\mathrm{dMO}$ is based on the close relationships found between the in vivo $\mathrm{dE}$ and $\mathrm{dOM}$ of foods $\left(\mathrm{r}^{2}=0.95\right.$; $\mathrm{RSD}=1.05 ; \mathrm{CV}=1.2 \%$ ) and between thein vivo and in vitro $\mathrm{dOM}\left(\mathrm{r}^{2}=0.92 ; \mathrm{RSD}=1.38 ; \mathrm{CV}=1.6 \%\right)$. 
Figure 6 shows the relationship found between the in vivo $\mathrm{DE}$ and that calculated by multiplying the GE determined in a bomb calorimeter by the $\mathrm{dE}$ predicted from the equation established between in vivo $\mathrm{dE}$ and in vitro $\mathrm{dMO}$.

Those authors validated this methodology using an independent database of 17 commercial extruded dog foods (Hervera et al., 2008). The results obtained showed more accurate predictions using the in vitro method than the modified-Atwater factors (NRC, 1985) or the NRC (2006) proposal (Table 3 ). Inclusion of a third step with bacterial carbohydrases initially does not seem to give better results than two-step incubation (data not published).

Energy evaluation by near-infrared reflectance spectroscopy

Near infrared reflectance spectroscopy (NIRS) has become a very powerful tool for rapid estimation of chemical composition and nutritive evaluation of feeds and compound diets (Givens \& Deaville, 1999). It is fast, inexpensive, and does not require chemical reagents. Moreover, several composition and nutritive evaluation parameters from the same sample can be analysed simultaneously and no sample preparation is required. Over the last decades, NIRS has been extensively used to estimate nutritive and energy value of feed ingredients and diets use in farm animal nutrition. However, very few studies have been published using NIRS as assessment tool of composition and nutritive value of pet food, probably because of the difficulty in obtaining enough in vivo data for a robust calibration.

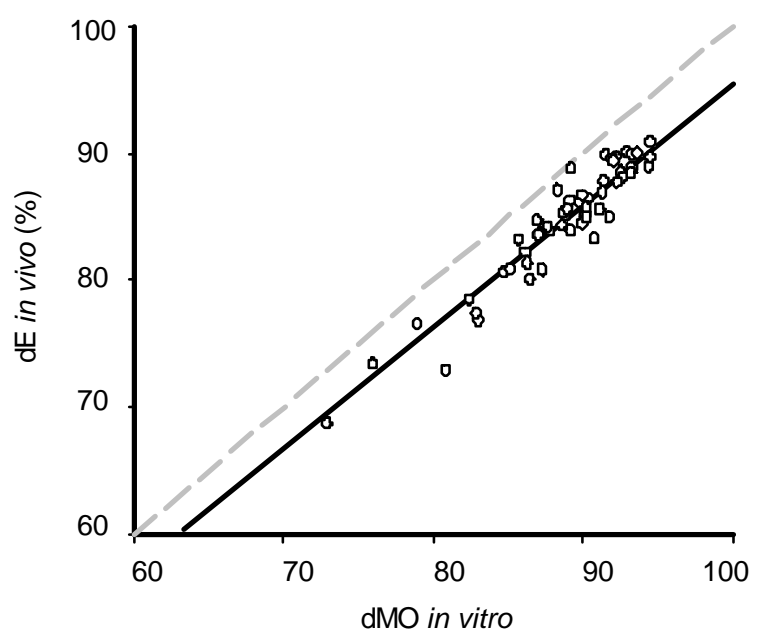

Figure 5 - Relationship between the dMO obtained from the in vitro method ( $\mathrm{dOM}$ in vitro) and the $\mathrm{dE}$ measured in vivo (dE in vivo) (Adapted from Hervera et al., 2007). $\left(\mathrm{dE}\right.$ in vivo $(\%)=-2.45+0.98 \pm 0.04 \mathrm{dOM}$ in vitro $(\%), \mathrm{r}^{2}=0.92$, $\mathrm{rsd}=1.25, \mathrm{CV}=1.5 \%$ )

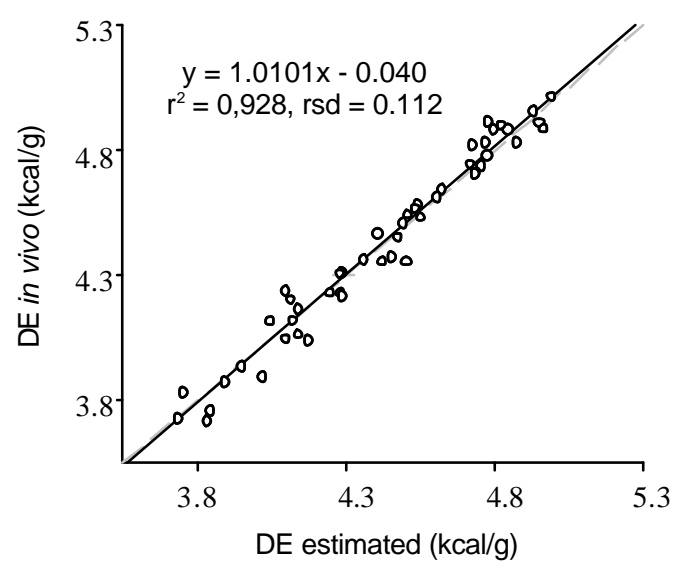

Figure 6 - Relationship between the DE estimated from the in vitro method and DE determined in vivo $(\mathrm{kcal} / \mathrm{g} \mathrm{DM})$ (Adapted from Hervera et al., 2007).

$\left[\mathrm{DE}\right.$ in vivo $=-0.08+1.02 \pm 0.02 \mathrm{DE}$ estimated, $\mathrm{r}^{2}=0.97 ;$ $\mathrm{rsd}=0.06 ; \mathrm{CV}=1.4 \%)$.

Castrillo et al. (2005) performed calibration equation for proximal composition, $\mathrm{GE}, \mathrm{dE}$ and $\mathrm{DE}$ content using 56 commercial extruded dry dog foods, with good results. The coefficients of determination of cross-validation were above 0.9 except for $\mathrm{dE}(0.87)$, and the standard errors associated with the cross-validation equations were also relatively low (coefficients of variation of $1.3 \%, 1.9 \%$ and $2.6 \%$ for GE, $\mathrm{dE}$ and DE, respectively. The lower precision of $\mathrm{dE}$ estimation compared with GE is expected because $\mathrm{dE}$ depends on feed characteristics as well as animal response to feeding.

Figure 7 shows the close relationship found between measured and NIRS predicted GE $(r=0.96, \mathrm{rsd}=0.069 \mathrm{kcal} /$ g DM), which was better than that obtained when GE was calculated from modified Atwater factors $(r=0.92$, $\mathrm{rsd}=0.096 \mathrm{kcal} / \mathrm{g} \mathrm{DM})$. Variation in GE is mainly determined by fat and protein food content, which were predicted with great accuracy by NIRs ( $\mathrm{r}^{2}$ cross-validation, 0.91 and 0.99 , respectively).

NIRs predicted DE of foods fitted better with in vivo measured values $(r=0.96, r s d=0.11 \mathrm{kcal} / \mathrm{g}$ DM) (Figure 8$)$ than DE estimated from chemical constituents assuming DE contents of $4.5,8.5$ and $3.5 \mathrm{kcal} / \mathrm{g}$ for $\mathrm{CP}$, EE and NFE, respectively $(r=0.93, \mathrm{rsd}=0.16 \mathrm{kcal} / \mathrm{g} \mathrm{DM})$ or calculated by multiplying the measured GE of food by their dE estimated from the equation obtained by Castrillo et al. (2001b) $(\mathrm{dE}=94.0-4.04 \mathrm{CF}),(\mathrm{r}=0.94, \mathrm{rsd}=0.14 \mathrm{kcal} / \mathrm{g} \mathrm{DM})$.

As shown in Table 3, the $\mathrm{dE}$ and DE predicted by NIRS with the independent database of 17 dry dog foods (Hervera et al. 2008) explained $87 \%$ and $93 \%$ of in vivo variations. The 
Table 3 - Relationship between in vivo Ed (\%) and in vitro estimated Ed (\%), and between in vivo DE (kcal/g DM) and in vitro estimated DE (kcal/g DM by the different methods $(\mathrm{n}=17)$ (Hervera et al., 2008)

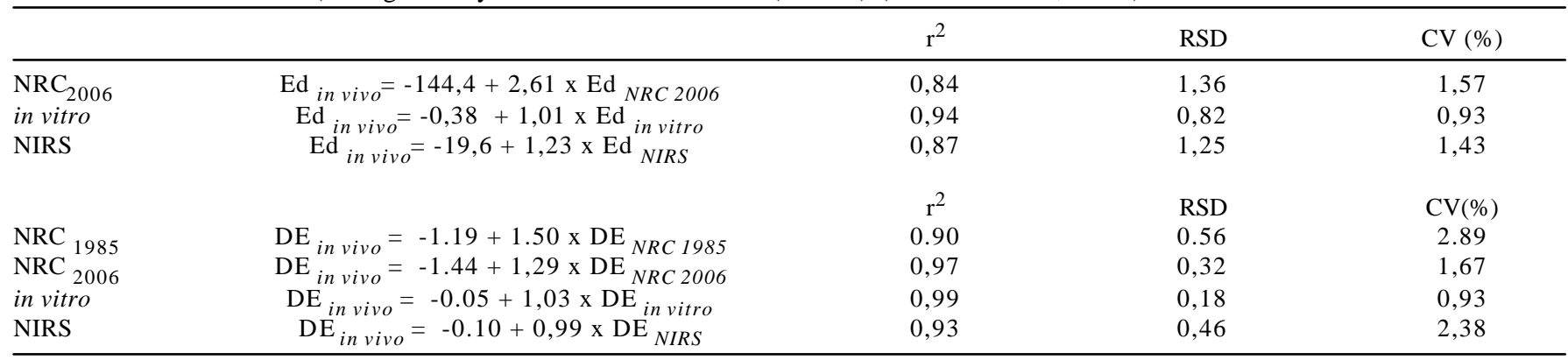

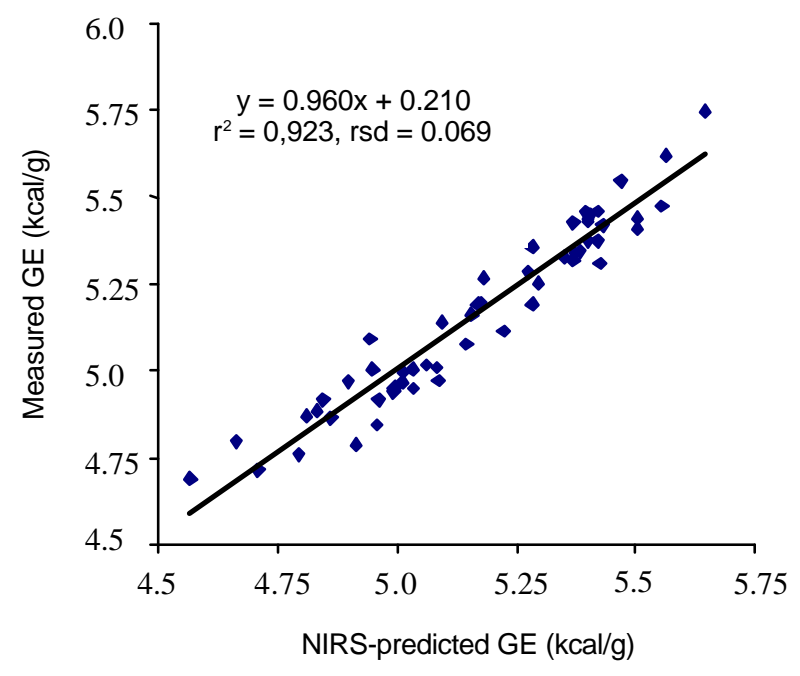

Figure 7 - Relationship between NIRS-predicted and measured $\mathrm{GE}(\mathrm{kcal} / \mathrm{g} \mathrm{DM})$ of compound dog foods. (Adapted from Castrillo et al., 2005).

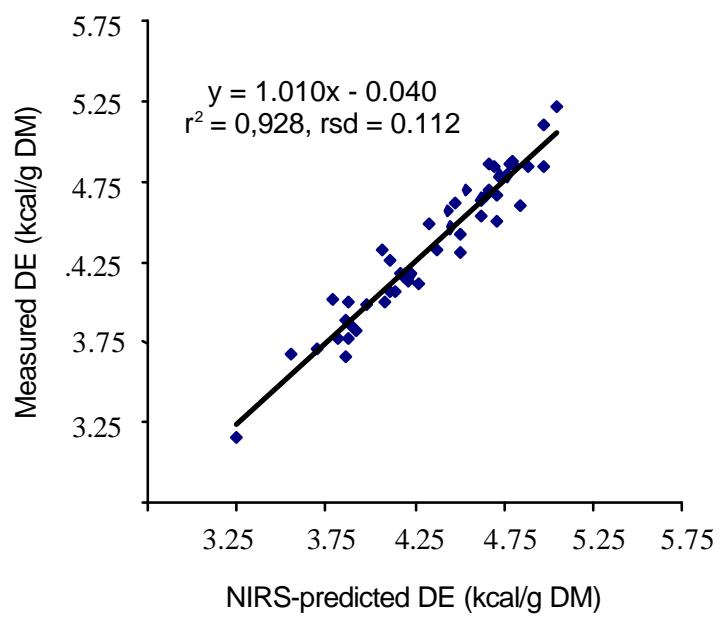

Figure 8 - Relationship between NIRS-predicted and in vivo measured DE (kcal/g DM) of compound dog foods. (Adapted from Castrillo et al., 2005). accuracy of dE prediction with NIRS was better than that obtained using constant factors (NRC, 1985), and similar or even better to that obtained using the NRC (2006) approach. The accuracy of DE prediction was slighter lower with NIRS than when using the NRC (2006) approach (CV =2.38vs 1.67, respectively). The best adjustments between calculated and in vivo $\mathrm{dE}$ and $\mathrm{DE}$ were obtained using the in vitro method proposed by Hervera et al. (2007). It is interesting to note that in estimations of DE by the in vitro or NRC (2006) approach measured values of GE were used, whereas in the NRC (1985) and NIR approach no information about GE content of food was used to obtain estimated DE. It was concluded that the three methods tested (NRC, 2006, NIRS and in vitro), are good alternatives to in vivo trials, and that in vitro method is slightly superior to the other two.

\section{Conclusions}

The new NRC approach to estimate ME from dE predicted by food fibre content, gives in general more accurate predictions than previously proposed modifiedAtwater factors, although some uncertainty exist for high fibre foods. The two-stepinvitro method has been shown to give good predictions of $\mathrm{dE}$ over a large range of extruded dog foods, and NIRS has been shown to be a very useful tool as an alternative support method to routine analytic feed assessment. In any case, considering the great variation in energy requirements between individual dogs and cats depending on breed, age, body size and body condition, insulation characteristics, activity, environment and housing conditions, state of health and even temperament, a key point is whether it is worthwhile continuing to try to find indirect methods to predict the ME content of food with greater accuracy to that obtained with the methods proposed to date. Furthermore when the requirements are established in $\mathrm{ME}$, differences in the efficiency of utilization of ME depending on absorbed 
metabolites are not considered, leading to an underestimation of ME needs when high-fibre or highprotein diets are used.

\section{Literature Cited}

\section{ASSOCIATION OF AMERICAN FEED CONTROL OFFICIAL -} AAFCO. Official Publication: 2008.

ATWATER, W.O. On the digestibility and availability of foods materials. Storrs: Agricultural Experimental Station, 1902. (Animal Report, 14)

ATWATER, W.O. Principles of nutrition and nutritive value of foods. Washington, D.C.: U.S. Department of Agriculture, 1910. (Farmer's Bulletin, 142).

BANTA, C.A.; CLEMENS, E.T.; KRINSKY, M.M. et al. Sites of Organic-acid production and patterns of digesta movement in the gastrointestinal tract of dogs. Journal of Nutrition, v.109, n.9, p.1592-1600, 1979.

BLAXTER, K. Energy metabolism in animals and man. Cambridge University Press, 1989. 336p.

BOISEN, S. A model for feed evaluation based on in vitro digestible dry matter and protein In: FULLER, M.F. (Ed.) In vitro digestion in pigs and poultry. Wallingford: $C A B$ International, 1991. p.135-146.

BOISEN, S. In vitro digestibility methods: history and specific approach In: MOUGHAN, P.J.; VERSTEGEN, M.W.A.; VISSERREYNEVELD, M.I. (Eds.). Feed evaluation. Principles and practice. Wageningen: Wageningen Press, 2000. p.153-168.

BOISEN, S.; EGGUM, B.O. Critical evaluation of in vitro methods for estimating digestibility in simple-stomach animals. Nutrition Research Reviews, v.4, p.141-162, 1991.

BOISEN, S.; FERNÁNDEZ, J.A. In vitro digestion as a basis for the prediction of energy and protein value in pig feeds. In: ANNUAL MEETING OF EUROPEAN ASSOCIATION OF ANIMAL PRODUCTION, 42., 1991, Berlin. Report...Berlin, 1991.8p.

BOISEN, S.; FERNANDEZ, J.A. Prediction of the total tract digestibility of energy in feedstuffs and pig diets by in vitro analyses. Animal Feed Science and Technology, v.68, n.3/ 4, p.277-286, 1997.

CASTRILlO, C.; BAUCELlS, M.; VICENTE, F. et al. Energy evaluation of extruded compound foods for dogs by near-infrared spectroscopy. Journal of Animal Physiology and Animal Nutrition, v.89, n.3/6, p.194-198, 2005.

CASTRILLO,C.; VICENTE,F.; GUADA, J.A. The effect of crude fibre on apparent digestibility and digestible energy content of extruded dog foods. Journal of Animal Physiology and Animal Nutrition, v.85, n.7/8, p.231-236, 2001a.

CASTRILLO, C.; VICENTE, F.; GUADA, J.A. Urinary energy losses in dogs fed commercial extruded foods. Journal of Animal Physiology and Animal Nutrition, v.85, n.7/8, p.237-241, $2001 \mathrm{~b}$.

DIEZ, M.; HORNICK, J.L.; BALDWIN, P. et al. The influence of sugar-beet fibre, guar gum and inulin on nutrient digestibility, water consumption and plasma metabolites in healthy Beagle dogs. Research in Veterinary Science, v.64, n.2, p.91-96, 1998.

EARLE, K.E.; KIENZLE, E.; OPITZ, B. et al. Fiber affects digestibility of organic matter and energy in pet foods. Journal of Nutrition, v.128, n.12, p.2798S-2800S, 1998. (suppl).

ENGLYST, H.N.; CUMMINGS, J.H. Improved method for measurement of dietary fiber and non-starch polysaccharides in plant foods. Journal of the Association of Official Analytical Chemists, v.71, n.4, p.808-814, 1988.

FAHEY JR., G.C.; MERCHEN, N.R.; CORBIN, J.E. et al. Dietary fiber for dogs: II. Iso-total dietary fiber (TDF) additions of divergent fiber sources to dog diets and their effects on nutrient intake, digestibility, metabolizable energy and digesta mean retention time. Journal of Animal Science, v.68, n.12, p.4229-4235, 1990.

FEDIAF. European pet food industry federation. Nutritional guidelines for complete and complementary pet food for cats and dogs. 2008. 76p.

GIVENS, D.I.; DEAVILLE, E.R. The current and future role of near infrared reflectance spectroscopy in animal nutrition: a review. Australian Journal of Agricultural Research, v.50, n.7, p.1131-1145, 1999 .

GRÖNER, T.; PFEFFER, E. Estimation of digestible energy in dry extruded dog foods. Journal of Animal Physiology and Animal Nutrition, v.77, n.4-5, p.207-213, 1997.

HERVERA, M.; BAUCELLS, M.D.; BLANCH, F.; CASTRILLO, C. Prediction of digestible energy content of extruded dog food by in vitro analyses. Journal of Animal Physiology and Animal Nutrition, v.91, n.5-6, p.205-209, 2007.

HERVERA,M.; BAUCELLS,M.D.; TORRE, C. et al. Prediction of digestible energy value of extruded dog food: comparison of methods. Journal of Animal Physiology and Animal Nutrition, v.92, n.3, p.253-259, 2008.

KENDALL, P.T.; BURGER, I.H.; SMITH, P.M. Methods of estimation of the metabolizable energy content of cat foods. Feline Practice, v.15, n.2, p.38-44, 1985.

KENDALL, P.T.; HOLME, D.W.; SMITH, P.M. Comparative evaluation of net digestive and absorptive efficiency in dogs and cats fed a variety of contrasting diet types. Journal of Small Animal Practice, v.23, p.577-587, 1982b.

KENDALL, P.T.; HOLME, D.W.; SMITH, P.M. Methods of prediction of the digestible energy content of dog foods from gross energy value, proximate analysis and digestive nutrient content. Journal of Science and Food Agriculture, v.33, n.9, p.823-831, 1982c

KENDALL, P.T.; SMITH, P.M.; HOLME, D.W. Factors affecting digestibility and in-vivo energy content of cat foods. Journal of Small Animal Practice, v.23, p.538-554, 1982a.

KIENZLE, E. Further developments in the prediction of metabolizable energy (ME) in pet food. Journal of Nutrition, v.132, n.6, p.1796S-1798S, 2002 .

KIENZLE, E.; BIOURGE, V.; SCHONMEIER, A. Prediction of energy digestibility in complete dry foods for dogs and cats by total dietary fiber. Journal of Nutrition, v.136, n.7, p.2041S2044S, 2006

KIENZLE, E.; BUTTERWICK, R. Results from energy research in dogs. In: EUROPEAN SOCIETY OF VETERINARY AND COMPARATIVE NUTRITION, 2000, Amsterdam. Proceedings... The Netherlands: 2000. p.12.

KIENZLE, E.; DOBENECKER, B.; EBER, S. Effect of cellulose on the digestibility of high starch versus high fat diets in dogs. Journal of Animal Physiology and Animal Nutrition, v.85, n.5/6, p.174-185, 2001.

KIENZLE,E.; OPITZ, B. Bioavailability of energy. In: THE PURINA NUTRITION FORUM, 1999, St. Louis. Proceedings... St. Louis: 1999. p.44.

KIENZLE, E.; OPITZ, B.; EARLE, K.E. et al. The influence of dietary fibre components on the apparent digestibility of organic matter and energy in prepared dog and cat foods. Journal of Animal Physiology and Animal Nutrition, v.79, n.1 p.4656, 1998a.

KIENZLE, E.; OPITZ, B.; EARLE, K.E. et al. The development of an improved method of predicting the energy content in prepared dog and cat food. Journal of Animal Physiology and Animal Nutrition, v.79, n.2 p.69-79, 1998b.

KIENZLE, E.; SCHRAG, I.; BUTTERWICK, R. et al. Calculation of gross energy in pet foods: Do we have the right values for heat of combustion? Journal of Nutrition, v.132, n.6, p.1799S-1800S, 2002.

KUHLMAN, G.; LAFLAMME, D.P.; BALLAM, J.M. A simple method for estimating the metabolizable energy content of dry cat foods. Feline Practice, v.21, n.2, p.16-20, 1993. 
LAFLAMME, D.P. Determining metabolizable energy content in commercial pet foods. Journal of Animal Physiology and Animal Nutrition, v.85, n.7/8, p.222-230, 2001

LIVESEY, G. Metabolizable energy of macronutrients. American Journal of Clinical Nutrition, v.62, n.5, p.S1135-S1142, 1995. McDONALD, P.; EDWARDS, R.A.; GREENHALGH, J.F.D. et al. Animal nutrition. 6.ed. Prentice Hall, 2002. 692p.

MCKAY,L.F.; EASTWOOD, M.A. A comparison of bacterial fermentation end-products in carnivores, herbivores and primates including man. Proceedings of the Nutrition Society, v.43, n.1, p.A35, 1984.

NGUYEN, P; DUMON, H.; MARTIN, L. The energy value of cat foods. Amsterdam: European Society of Veterinary anda Comparative Nutition, 2000. p.9.

NOTT, H.M.; RIGBY, S.I.; JOHNSON, J.V. et al. Design of digestibility trials for dogs and cats. Journal of Nutrition, v.124, n.12, p.2582S-2583S, 1994 (suppl).

NATIONAL RESEARCH COUNCIL - NRC. Nutrient requirements of dogs. Washington, D.C.: National Academy Press, 1985. 79p.

NATIONAL RESEARCH COUNCIL - NRC. Nutrient requirements of cats. Washington, D.C.: National Academy Press, 1986. 78p.

NATIONAL RESEARCH COUNCIL - NRC. Nutrient requirements of dogs and cats. Washington, D.C.: 2006. $397 p$.

OHSHIMA, S.; FUKUMA, Y.; SUZUKI, T. et al. Estimation of nitrogen-corrected metabolizable energy value of laboratory canine diets. Jikken Dobutsu (Experimental Animals), v.42, n.4, p.571-577, 1993.

PROSKY, L.; ASP, N.G.; FURDA, I. et al. Determination of total dietary fiber in foods and food products: collaborative study. Journal of the Association of Official Analytical Chemists, v.68, n.4, p.677-679, 1985.

RUBNER, M. Calorimetrische untersuchungen (Calorimetric investigations). Zeitschrift fur Biologie, v.42, p.261275. 1985. (quoted by Kienzle \& Opits, 1999: original not seen).

SHIELDS, R.G. Digestibility and metabolizable energy measurement in $\operatorname{dogs}$ and cats. In: PET FOOD FORUM, 1993, Morris M. Proceedings... Morris M., 1993. p.21.

SILVIO, J.; HARMON, D.L.; GROSS, K.L. et al. Influence of fiber fermentability on nutrient digestion in the dog. Nutrition, v.16, n.4, p.289-295, 2000.

SMEETS-PETTERS, M.J.E; MINEKUS, M.; HAVENAAR, R. et al. Description of a dynamic in vitro model of the dog gastrointestinal tract and an evaluation of various transit times for protein and calcium. Atla-Alternatives to Laboratory Animals, v.27, n.6, p.935-949, 1999.

TESHIMA E; CARCIOFI AC; BRUNETTO M.A. et al. Prediction equations of metabolizable energy of commercial diets for dogs with different nitrogen-free extract manufactured in Brazil. In: CONGRESS OF THE EUROPEAN SOCIETY OF VETERINARY AND COMPARATIVE NUTRITION, 11., 2007, Leipzig. Proceedings... Leipzig: 2007. p.94. 